\title{
ELECTORAL VIOLENCE UNDER DIFFERENT CONTEXTS. EVIDENCE FROM THE WESTERN BALKANS
}

\author{
MiCHAL MOCHTAK \\ INSTITUTE OF POLITICAL SCIENCE | UNIVERSITY OF LUXEMBOURG \\ (MICHAL.MOCHTAK@UNI.LU)
}

\section{Introduction}

Election as a unique space for controlled conflict has become the ultimate modus operandi for selecting the candidates for public offices all around the world. Although the contentious nature of elections usually does not stimulate conflict behaviour, the logic of confrontation and stakes at play might give rise to issues which occasionally escalate into open hostility or even violence (Mansfield and Snyder 2005). This particular subcategory of political violence, here labelled as electoral violence, can be defined as acts of physical or psychological violence that disturb the electoral competition and its outcome. These instances are distinguished from other criminal activities by their direct relationship to the events, personalities and issues comprising an electoral contest (Höglund 2009; Rapoport and Weinberg 2001). In this context, electoral violence is understood as a unique subcategory of political violence based on timing, a relationship to specific issues, instrumentality (violence intended to achieve defined goals) and consequences, all in connection to electoral arenas (Norris, Frank, and Martínez i Coma 2015). Although existing literature identifies factors which might play a role in the outbursts of electoral violence, covering small-scale incidents as well as massive forms of violent confrontation, its empirical basis remains rather limited with primarily focus on conflict-ridden societies in Africa and Southeast Asia. In order to address this empirical limitation, this paper analyses potential drivers of electoral violence in the Western Balkans ${ }^{1}$ and discusses how a general set of electoral qualities interacts with the electoral contexts under which election is organized.

Most of the published papers in recent years have focused on electoral violence either from the macro-structural perspective with statistical models identifying factors potentially responsible for the escalation of violence (Fjelde and Höglund 2015; Gutiérrez-Romero 2014; Hafner-Burton, Hyde, and 
Jablonski 2013) or they have followed a more case-based approach in order to understand the specific instances of the phenomenon in space and time of a single case or a small number of cases (Boone and Kriger 2012; Sisk 2012; Wilkinson 2004). Although their findings have been insightful, the phenomenon of electoral violence is still understudied with a strong bias toward cases that are extreme in terms of fatalities and consequences. The reality is however far more complex. Electoral violence does occur in all sorts of environments, societies and regimes, covering regions of Eastern Europe, Latin America, Africa, Asia but also the Western World where violent incidents, although not disastrous in terms of total chaos and anarchy, are serious enough to warrant our attention (Norris 2014; Norris, Frank, and Martínez i Coma 2015).

The paper addresses the question of what settings are empirically relevant for the occurrence of electoral violence in the region of Western Balkans and what theoretical paths may cover their logic (?). The paper specifically focuses on seven broadly discussed preconditions that are seen as relevant for causing tension during elections in general: low quality of democracy, ethnic diversity, bad economic performance, violation of principles of rule of law, capacities and independence of electoral management bodies, proportionality of electoral system, and dynamics of close electoral competition (Fjelde and Höglund 2015; Opitz, Fjelde, and Höglund 2013; Reilly 2001). The Western Balkans seem to be a perfect region for testing these expectations as it has come a long way since the early 1990s when ethnic tension, historical grievances, economic stagnation and authoritarian tendencies escalated into the most violent conflict in Europe since the end of World War II. The paper applies fuzzy-set qualitative comparative analysis (fsQCA) in order to address the potential configurational nature of roots of electoral violence and to understand their equifinal logic (meaning that the various [combinations of] conditions can produce the same outcome).

The paper analyses original data on electoral violence collected from the Organization for Security and Co-operation in Europe (OSCE) monitoring reports on 56 parliamentary elections in the region between 1990 and 2015. The results show that electoral violence can be explained by multiple paths indicating a fairly complex nature of the phenomenon. The paper finds four empirically robust paths under which electoral violence in the region occurs combining macro structural drivers of 
contentious behaviour with conflict logic of electoral competition. We argue that although the studied conditions are relevant in other regions as well, their combinations identified as potential paths to electoral violence are context relevant reflecting the unique nature of the region under study. Moreover, as the results show, none of the studied conditions potentially affecting occurrence of electoral violence in the Western Balkans appears to be sufficient for the outcome on its own, a finding often overlooked by scholars in general.

The paper is organized as follows. First part briefly discusses potential roots and drivers of electoral violence and defines conditions that are going to be tested. The second part presents the analytical framework of fsQCA and addresses the problem of model ambiguity which, despite its relevancy, has not been properly addressed in most published studies in general. Third (analytical) part presents the analysis itself and discusses the results in the context of the Western Balkans. Conclusions then summarize the findings and present potential implications for future research.

\section{Roots of electoral violence}

Research on electoral violence has focused in recent years on understanding the strategies and efforts to influence electoral outcomes. Most of the published papers are devoted to the study of electoral manipulation in which political elites, as well as political entrepreneurs, seek to influence the outcome of elections by circumventing democratic procedures. Electoral violence is in this context often discussed as one of available strategies and a tool for reducing the uncertainty of the electoral contest or influencing the post-electoral situation following the announcement of results (Dunning 2011).

The existing literature identifies number of context- and election- related factors potentially responsible for occurrence of electoral violence. It has traditionally been seen as a way of manifesting political instability during transformation processes and/or as a tool for advancing the goals and strategies of authoritarian/hybrid regimes (Huntington 1991; Levitsky and Way 2002; Schedler 2002). In recent years, academics have developed a more complex approach where the phenomenon of electoral violence is seen not merely as a sole by-product of troubled political liberalization, but it may 
also play a significant role in electoral campaigning (Birch and Muchlinski 2018; Norris, Frank, and Martínez i Coma 2015). Arriola and Johnson (2012) identify clientelistic corruption as a potential driver of electoral unrest. Hafner-Burton, Hyde, and Jablonski (2013) see the loss of incumbent elites as a risk factor which may escalate violent clashes and deepen existing tensions. Pevehouse, Straus, and Taylor (2012) stress that most violence in Sub-Saharan Africa is committed by incumbents seeking re-election. They further add that pre-existing social conflict and the quality of founding elections shape pre-election violence, while the stability of democratic institutions and weaker economic growth shape violence after polling stations close (cf. Kuhn 2015). Several other theories emphasise the importance of the structure of the electoral system and the effectiveness of related institutions (Lijphart 1977; Linz 1990; Sisk 1998), ethnic tensions (Horowitz 1985; Wilkinson 2004), and a country’s socio-economic situation as factors which may ignite violent confrontation during elections (Collier 2009; Londregan and Poole 2011). As Mochtak showed, majority of these drivers are empirically relevant also in post-communist countries which allows us to expect theoretical validity in the Western Balkans as well (2016).

In order to systematize this discussion, the paper’s framework finds its inspiration in the work of Kristine Höglund who has identified three main areas of enabling conditions and triggering factors potentially responsible for the occurrence of electoral violence (Höglund 2009): 1) the nature of politics based on existing conflict cleavages and different forms of patronage, 2) the nature of elections as a form of competition and mobilization, 3) and the capacities of electoral institutions. Although relatively vague, the first area refers to the remote/contextual level of potential drivers of elctoral violence, while the remaining two cover more proximate/election-specific factors of electoral competition. This division creates a very basic structure of an analytical framework that can be further developed and tested. As such, remote factors refer to more general drivers of political life which go beyond the electora arenas and electoral competition. On the other hand, proximate factors affect dynamics and interactions in electoral arenas which extensively interact with broader political landscape but rarely leave the context of electoral competition.

When it comes to a discussion about specific pre-conditions, it is important to mention that the existing research is strongly influenced by traditional approach focused on institutional weakness 
affected by authoritarian rule, democratic transition, or post-conflict settlement (Arriola and Johnson 2012; Höglund 2009). Hafner-Burton, Hyde, and Jablonski even postulate that potential absence of institutional constraints on governments may encourage the use of violent electoral strategies in order to preserve the ruling domain in the hands of incumbents (Hafner-Burton, Hyde, and Jablonski 2013). This paper follows this diction and develops a framework where remote contextual preconditions interact with more proximate factors associated with electoral arenas and the qualities of electoral competition. In other words, institutional settings are inherently connected with the context under which they are implemented. This approach deviates from what is seen by most studies in the field as the standard procedure as it focuses on interaction of conditions (variables) rather than on their unique significance. In other words, we assume that all the considered conditions are relevant under certain circumstances but we do not know when and where.

Based on this configurational rationale, the paper focuses on those factors that appear to be empirically most robust in the Western Balkans (compare Gordon 2013; Hayden 2013; Keil 2014) and, at the same time, are part of the core discussion on drivers of electoral violence in general (see above). This approach identifies seven potential conditions affecting electoral violence in the region which are tested for empirical relevance for the outcome. Low quality of democracy (LQD), ethnic diversity (ED), bad economic performance (BEP), and violation of principles of rule of law (VRL; as a proxy for system of patronage and corruption) represent macro-structural factors potentially responsible for escalation of electoral violence. Although not exhaustive, these four factors do represent political, judicial, economic, and ethno-cultural dimensions, all extremely relevant as potentially contributing to the occurrence of electoral violence in the region (cf. Appendix A).

Macro structural factors are further combined with micro-level drivers rooted in electoral arena and defining dynamic part of an electoral competition. Low capacities of electoral management body (LEMB), unproportional electoral system (UPES), and dynamics of close electoral competition (CC) represent the core electoral settings often discussed as triggering factors for contentious elections (cf. Birch 2011; Keil 2014; Norris 2014; Opitz, Fjelde, and Höglund 2013). The goal is to understand how the most discussed drivers of electoral violence identified by number of studies interact with different 
contexts in a region where similar dynamics may exist but have been never tested (calibration for all the conditions is summarized in Appendix B).

\section{Method and Data on Electoral Violence}

The paper applies fsQCA to a theoretical framework that tries to identify a set of specific paths to electoral violence in the Western Balkans. The motivation to use fsQCA is driven by an effort to identify potential configurations explaining context-specific types of electoral violence present in the region under study. Moreover, fsQCA is applied in order to handle two aspects of causal complexity that are of core theoretical interest to this paper: equifinality and conjunctural causation (Bara 2014; Ragin 2008; Schneider and Wagemann 2012). Equifinality refers to a situation where multiple paths to the same outcome may exist, that is, that electoral violence may be the result of different configurations of potentially relevant conditions. Conjunctural causation on the other hand refers to a setting in which the effect of one condition depends on the presence or absence of other conditions (Ragin 2000).

The conditions here are understood as INUS conditions which means they are insufficient but necessary parts of paths which are themselves unnecessary but sufficient for the result (Mackie 1965). In other words, in term $\mathrm{A} * \mathrm{~B}+\sim \mathrm{B}^{*} \mathrm{C} \rightarrow \mathrm{Y}$ condition $\mathrm{A}$ exerts its effect on $\mathrm{Y}$ only in combination with condition B. It is therefore insufficient on its own but needed (i.e., necessary) to form a sufficient conjunction together with $\mathrm{B}$. The sufficient conjunction $\mathrm{A}^{*} \mathrm{~B}$, in turn, is not the only path to the outcome, i.e., it is unnecessary. Thus, condition A alone is, as the definition goes, insufficient, but it is a necessary part of a conjunctural condition which is itself unnecessary but sufficient for the result. It can be seen that INUS conditions are closely tied to the equifinal and conjunctural character of causal complexity. Equifinality shows that there are alternative sufficient conditions. Therefore, equifinal causal relations are mirrored in the "condition which is itself unnecessary but sufficient for the result" from the INUS definition. The notion of conjunctural causation refers to that part of the definition which described INUS conditions as "insufficient but necessary parts of a condition." In other words, single conditions are often not sufficient on their own, but need to be combined with others (Schneider and Wagemann 2012, 79). 
As we have shown in the theoretical discussion, we already can assume that the conditions under study are potentially relevant for the occurrence of electoral violence. The following factor frame tries to identify how they are relevant. The paper omits any broad discussion introducing fsQCA, which can easily be found in the respective methodological literature (Ragin 2008; Rihoux and Ragin 2009; Schneider and Wagemann 2012), and rather briefly focuses on a problem of model ambiguities that exists in most of the empirical applications of QCA. As the paper is one of only few applications that recognizes the existence of potential model ambiguities, its empirical relevance stretches to methodological discussion on a good practice in QCA as well (compare Haesebrouck and Thiem 2017).

Model ambiguities refer to a problem in the QCA applications arising when multiple causal models fare equally well in accounting for configurational data. Due to application of an algorithm unsuitable for causal modelling that is currently present in most of the available analytical tools, researchers tend to select only one of the alternative models often fully unaware of the existence of a more complex model space with multiple models. QCA analysis faces model ambiguities whenever a PI chart (prime implicants chart) results contain columns that are exclusively covered by inessential prime implicants, so-called orphan columns. Whether ambiguities arise or not is highly sensitive to the peculiarities of a processed truth table. As such, model ambiguities are an undesirable result because they may diminish, and sometimes completely erase, the informativeness of the conclusions that can be drawn from a study. In other words, the more models exist that account equally well for the data, the less definite the conclusions that can be drawn. At the same time, this kind of result can produce a much more robust insight based on complex overview of the whole model space without its unfounded reduction that has not theoretical as well empirical justification (Baumgartner and Thiem 2017a, 3). A good practice, adopted by this paper as well, is therefore to explicitly report all the alternative models and transparently discuss them to what degree the analysed data underdetermine the causal modelling as a result of QCA analysis (Baumgartner and Thiem 2017a).

Based on the theoretical discussion presented in the previous section and the methodological remarks on QCA and model ambiguities, fsQCA analyses configurations of seven conditions LQQD, ED, BEP, VRL, UPES, LEMB, CC $\}$ against the outcome of electoral violence $\{E V\}$ in order to identify 
potential explanatory paths for electoral violence in the region of Wester Balkans. The analytical part applies fsQCA using the R package QCApro version 1.1-2 which is currently the only analytical tool explicitly considering the problem of model ambiguities (Thiem 2018). Raw data are calibrated based on external criteria coming from the theoretical discussion and empirical evidence at hand (see Appendix B).

Before presenting the analytical steps and the results, the operationalization/calibration of the outcome - electoral violence - needs to be briefly discussed. Data on electoral violence are collected from the monitoring reports prepared by the Organization for Security and Cooperation in Europe. They are further supported by findings of the International Republican Institute (IRI) and the European Union (EU). One exception is the period of the early 1990s when a systematic effort to monitor elections in the Western Balkans did not exist. This gap is overcome by other sources including books, academic papers, and media coverage. Electoral violence is coded as a combination of three dimensions - form (soft/hard) ${ }^{2}$, organization (individual/collective) $)^{3}$, and salience (low/high) ${ }^{4}-$ in order to grasp the dynamic nature of contentious behaviour during the elections and systematically approach its various types (cf. Tilly 2003). Since there are three indicators, each of which may have two values (form [A]: soft[1]/hard[2]; organization[B]: individual[1]/collective[2]; salience [C]: low[1]/high[2]), eight possible combinations that can be ordered as set-membership scores are available (A1B1C1; A1B1C2; A1B2C1; A1B2C2; A2B1C1; A2B1C2; A2B2C1; A2B2C2). The presence of electoral violence is coded on a scale from zero to one, where zero (0) refers to no electoral violence at all and one (1) to massive incidents of electoral violence with physical attacks (hard form of electoral violence), collective organization and high salience (see the coding in Table 1). The hierarchy is based on an assumption concerning the intensity of electoral violence and its potential impact (massive incidents of electoral violence are seen as more serious and dangerous).

[Table 1. Coding and calibration of electoral violence]

Each election under study (covering approximately the period of 90 days before and 90 days after the polling day) is examined for the presence of incidents of electoral violence. Incidents are then 
grouped and assessed based on prevailing patterns that are observed. Set-membership scores are assigned against evaluation of three aforementioned dimensions and their combinations. The dataset consists of 56 parliamentary elections organized in the period of 1990 - 2015. Out of 56 elections, 32 (57.14 per cent) witnessed electoral violence relevant enough to code it as more in than out of the respective set (the set-membership score $>0.5$ ). Although presidential elections might be analysed as well, the fact that not all countries in the region hold direct presidential election leads us to a decision not to cover them. Moreover, the logic and dynamics of presidential elections are different from the parliamentary ones and should be studied separately if possible.

The primary dimension in the context of dividing the scale of electoral violence is collectiveness. Empirically as well as theoretically it is appropriate to argue that collective acts are almost always more serious than individual acts because of the potential damage they can cause. It divides the scale of electoral violence into two parts, where first (the collective dimension) describes incidents that are more in than out of the set, while the second (the individual dimension) covers acts more out than in. The remaining two dimensions (form and salience) further divide the subsets and develop the complexity of the coding system. The logic of this process is however slightly different in both parts of the scale. In the case of the subset 'more-in-than-out', the second most important dimension is the level of salience (high/low), while the subset 'more-out-than-in' applies the dimension of the form (hard/soft) first. This logic comes from the collected data which suggests that collective acts of violence if combined with high salience, are usually part of a broader attempt to affect the electoral contest and its outcome. The form is just the manner in which the goals are pursued and often reflects the level of sophistication of those who use violent means. Individual acts of violence, on the other hand, deal with interpersonal confrontation that is more dangerous when hard violence occurs and when potential physical injuries are involved (although important, salience comes second in this nexus). It depicts a tree structure with a different logic for assignment fuzzy scores for the part more-in-than-out on one hand and more-out-than-in on the other. The paper does not divide the evidence based on timing (pre-election period, polling day, post-election period) or nature (top-down, bottom-up) as the configurational logic of QCA can handle it through the existence of multiple paths if relevant. 


\section{Analysis}

As was already discussed in the previous section, the tested factor frame consists of seven exogenous factors (conditions) \{LQD, ED, BEP, VRL, UPES, LEMB, CC $\}$ potentially explaining the outcome of electoral violence $\{\mathrm{EV}\}$. Inclusion threshold for the truth table is set at the level 0.75 with the minimum number of cases included being one (see truth table in Appendix C). In accordance with the recommendations of recent methodological advancements, we do not carry out isolated analyses of simple necessary conditions before proceeding to the Boolean minimization (Thiem 2016b). In response to the recent methodological dispute on interpretation of solution terms, the paper roots its analysis in the work of Michael Baumgartner and Alrik Thiem and follows a recommendation to report parsimonious solution as the only type of the three QCA solution types that is not methodologically biased (Thiem 2016a). Since recent methodological work has demonstrated that both the conservative and intermediate solution types often infer (way) beyond the data, and thus increase the risk of causal fallacies, it represents a safe approach for interpreting the results (Baumgartner and Thiem 2017b).

Before we approach the minimization procedure, we need to briefly inspect the truth table for any obvious counterfactual cases that may affect the robustness of our solution term. Although with empirical data it is often complicated to eliminate all of the existing counterfactuals, if possible, at least the most inconsistent cases need to be handled before further analytical steps are taken. An obvious candidate for this problem in our truth table is the combination of conditions [LEMB ${ }^{\{1\}}, \mathrm{UPES}^{\{0\}}, \mathrm{CC}^{\{0\}}$, $\mathrm{LQD}^{\{1\}}, \mathrm{ED}^{\{1\}}, \mathrm{BEP}^{\{1\}}, \mathrm{VRL}^{\{1\}}$, and $\left.\mathrm{OUT}^{\{0\}}\right]$, covering five cases three of which are empirically important for the studied phenomenon (see highlighted rows in Appendix C). The consistency rate of the row is rather low, only 0.57 , yet still covering the most violent period of the region's modern history with cases like 1992 and 1993 parliamentary elections in Serbia and 1990 parliamentary election in Bosnia and Herzegovina. The reported inconsistency is caused by somehow deviant case of Montenegro with no evidence on electoral violence reported in that period, yet still sharing similar macro-structural 
and institutional settings as the rest of the cases covered. It is potentially a result of a specific position of the League of Communists of Montenegro (later renamed to Democratic Party of Socialists) dominating the Montenegrin political landscape unanimously until its internal split in 1997. Part of the explanation might be also the utter dominance of Serbia in the forming federation, which until 1997 was not much questioned by the Montenegrin political representation and Montenegro acted more like a satellite than an independent state (Mochtak 2015). As this early stage of Montenegro's democratic transformation represents too unique story in our dataset causing serious inconsistencies in otherwise theoretically robust row(s), it is better to omit the 1990, 1992, and 1996 parliamentary elections as too deviant (cf. Darmanović 1992; Morrison 2018). Although it lowers the number of studied cases from 56 to 53, it positively affects the theoretical and empirical robustness of the solution. The new consistency rate of the discussed row jumps from 0.57 to 0.84 showing a theoretically rich path explaining part of the electoral violence in our dataset (see Table 2).

[Table 2. Truth table without deviant cases of Montenegro]

In the next step, QCApro's minimization algorithm identifies all paths that potentially explain electoral violence in the region. We follow the recommendation made by Baumgartner and Thiem and report the whole model space (see above). As Table 3 shows, there are four unique models identifying nine potential paths explaining electoral violence in the Western Balkans. Four out of nine of these paths (italicized) are present in all four models showing that these paths are empirically most relevant and are substantially important in explaining the outcome (EV). The remaining five are reported as empirical equivalents that cannot be further reduced based on empirical evidence yet still present an insightful story of how electoral violence might further occur.

[Table 2. Overview of a model space produced by minimization procedure]

This result is not surprising and reflects the complex reality we have observed in the Western Balkans in the past 25 years. The reported models (M1-M4) have relatively high consistency rate 
ranging from 0.81 to 0.82 and modest to high coverage ranging from 0.74 to 0.75 . This is relatively well performing solution with high theoretical relevancy explaining most of the cases under study. As we noted, four out of nine paths identified in the solution are present in all four models and therefore can be understood as empirically robust. Each one of them tells a story about how electoral violence in the region might be explained.

Some of the paths represent classic settings under which electoral violence often occurs and is broadly discussed (Höglund 2009; Norris, Frank, and Martínez i Coma 2015). The first path (ED*VRL) represents a classic context of ethnically diverse societies (ED) polarized through general violations of rule of law with severe impact on perception of state capacities and authority. When an election is organized, the ethnic aspect, seen as a simplified denominator for diversity, is combined with the expectations about the electoral outcome. Electoral violence is then used by some political entrepreneurs as a strategy that might bring the lacking fairness to those who either are subjectively or objectively deprived of something or are structurally disadvantaged. This rises stakes political actors and their supporters place in the competition. The path covers most of the elections in 1990s in Serbia and Bosnia and Herzegovina, and majority of elections in Macedonia.

Second path $\left(\mathrm{ED}^{*} \sim \mathrm{BEP}\right)$ is a derivation of the first path and covers a context in which improving economic performance ( BEP) cannot outplay ethnic diversity (ED) and prevent the occurrence of electoral violence during the election. The path covers most of the elections in Bosnia and Herzegovina (1996, 1998, 2000, 2002, 2006), Macedonia (1998, 2008, 2011, 2014), but also Montenegro (1998, 2006) where internal tension among various ethnic groups cause constant confrontation which is present in all arenas defining the public space. Ethnic diversity is a simple denominator for general otherness defined by ethnic, linguistic, cultural, or religious differences rather than a pure primordialistic notion of blood and kinship.

Third path (UPES* BEP), described through combination of improving economic performance ( BEP) and unproportional electoral system (UPES), tells a story of unfair competition often caused by institutional engineering benefiting one or few political parties that try to dominate the election. It covers two elections in Albania (1996, 2005) where the main political parties were notoriously known 
for monopolizing public space through institutional as well personal changes focused on safeguarding their positions.

Fourth path ( LEMB*LQD* BEP) covers another classic example of electoral violence scenario where low standards of democracy (LQD) outperforms general capacities of electoral administration ( LEMB) and improving economic performance ( $\sim \mathrm{BEP})$ as a driver for electoral violence. It covers most of the elections already discussed under the first path in Macedonia (2008, 2011, 2014) and Bosnia and Herzegovina (1996, 1998, 2000, 2002, 2006), but also 1995 parliamentary election in Croatia and 2000 parliamentary election in Serbia. The fact that electoral violence under this path occurs as a combination of low quality of democracy and improving economic performance suggests that electoral violence can occur also during periods of economic growth. This however must be understood in the regional context where most of the elections overlap with post-conflict economic reconstruction (after years of decline there is growth). In this context, the tension between the efforts to democratize and the autocratic backlash as a counteraction is predominantly characterized by the conflict that may or may not be resolved peacefully (Karl 1990). If not, parties may use force to pursue their goals and violently take control of a situation. Transformation is indeed about power struggles when the old system is deteriorating or breaking down, but the new one is still not established. These uncertainties open up a whole new dimension of interaction that may bring more violence of atrocities as an extra-legal strategies for achieving political goals (Linz and Stepan 1996).

As was already noted, these four paths are present in all four models, therefore can be seen as empirically consistent through all of them. Cases covered by multiple paths can be understood as having more than one explanation for the occurrence of electoral violence, referring to the principle of equifinality. As our model shows, 12 cases can be explained by more than one of the identified paths which provides an alternative perspective on nature of electoral violence and its escalation in general. This can explain why ethnic diversity and institutional shortcomings can cover the same incidents equally well not preferring one path over others. It gives us additional insight in the nature of the roots of electoral violence that are often complex and have a truly equifinal logic. 
Besides the four paths that are always present, the solution identifies five more configurations under which electoral violence is observed, yet because of lack of empirical evidence, we cannot decide which one is the most empirically relevant (see Figure 1). These five alternatives however cannot occur together and represent empirical alternatives that eliminate each other. If one occurs, the others cannot and vice versa. The configurations however tell us already a lot, as we can see that all of them combine close competition (CC) with contextually relevant insights combing good or improving socio-economic factors $\left(\mathrm{CC}^{*} \sim \mathrm{BEP}, \mathrm{CC} * \sim \mathrm{VRL}\right)$ or further obstacles (CC*ED, CC*LQD, CC*LEMB). Although we have five potential paths, they cover only three cases with a long history of contentions elections taking place, which makes it easier to summarize them empirically (Albania 2009, Macedonia 1998, and Montenegro 2001).

[Figure 1. Visualization of alternative paths]

The four identified models create a theoretical map of electoral violence in the Western Balkans. It represents a complex overview of paths combining macros-structural drivers with electiondriven dynamics that are context relevant and unique. It is important to stress again that the solution is quite robust. High consistency rates support the theoretical relevance of the results while coverage gauge its empirical weight. It is crucial to realize that coverage differs from consistency, and the two sometimes work against each other as high consistency may yield low coverage. High consistency as well as relatively high coverage in this case support the empirical as well as theoretical robustness of the results (Ragin 2006).

\section{Back to the Cases}

Identified paths and the logic behind them tell only half of the story about electoral violence in the Western Balkans. The other half is rooted in the discussion of the empirical relevance of the cases covered by the solution terms. The analysis has identified four models with nine unique paths which might be discussed as empirically relevant scenarios for the occurrence of electoral violence in the 
region. As each of the models is seen as an empirical alternative, they cannot be explained together. If one of them occurs the rest of them do not. We again start with four paths that are present in all of the models as we are sure they are empirically relevant in all the available alternatives. Each of these paths is visualized in a graph so it is easier to identify the most typical cases as well those violating the theoretical expectations. Summary of the paths are presented in Figure 2.

[Figure 2. Summary of paths and cases covered]

The most typical cases covered by the first path (ED*VRL) are parliamentary election in Serbia (1990, 1997), Bosnia and Herzegovina (1990, 1998), and Macedonia (2008, 2011, 2014). Serbia and Bosnia and Herzegovina stands as typical examples of conflict and post-conflict elections where ethnically polarized societies have to face various forms of unfair treatment and violations of rule of law on daily basis. Less known but still very interesting case here is Macedonia where the logic of ethnically divided society is mixed with various violations of rule of law producing frustration and hostility. The best example is the 2008 early parliamentary election called after Greece's veto of Macedonia's bid to join NATO at the 2008 summit in Bucharest. The election was organized in a tense atmosphere with Kosovo declaring independence from Serbia (accompanied by calls for its recognition), international disappointments (failed EU and NATO talks) but also political and social instability, corruption and low accountability, all affecting the perception of the election and its outcome (Koinova 2013; Neofotistos 2012). The election was heavily affected by clashes in Albanian dominated regions among groups of ethnic Albanians as well as Albanians and Macedonians. Some of the political parties representing ethnic Albanians used strong rhetoric against the Macedonian majority which was blamed for discrimination and oppression. Police was divided and generally paralyzed following the ethnic lines which led to more violence and hostilities. In cases when the police did intervene, the actions were limited and selective, often following political motivations of those in charge. The OSCE mission informed about number of attacks on administration offices, kidnapping incidents, attacks on political activists and shootings (OSCE 2008). 
The second path (ED* BEP) tells a story similar to the one presented above. While the first path described a context where ethnically diverse societies are further polarized through a general atmosphere of unfairness, the second path strongly refers to ethnic diversity that is accompanied by improving economic performance. The most typical cases here are again Macedonia (1998, 2006, 2008), Serbia (1997), Bosnia and Herzegovina (1998), and Montenegro (1998). Although ethnically driven conflicts as sole drivers of violence in the Western Balkans have been criticized by scholars all around the world, the importance of ethnic diversity in political arena can be hardly ignored (cf. Chandra 2012; Wimmer 2013). The best example of this logic can be demonstrated on the case of Montenegro. From the early 1990s Montenegro was a close ally of Serbia led by former Communists well connected to Slobodan Milošević and the regime in Belgrade. As there was no political conflict about the orientation of the country or its strategic allies, ethnic diversity was not an issue at all. According to 1991 census, $61.9 \%$ of the population claimed to be Montenegrins, while only $9.3 \%$ to be Serbs, with no electoral violence reported. A change comes with the political crisis in the second half of 1990s. In 1997, the country was divided by the internal strife within the Democratic Party of Socialists (DPS) resulting in nomination of two candidates running for the office of the president. Tensed atmosphere led to a close competition that escalated into hostilities when acting President and Milošević's associate Momir Bulatović refused to accept his defeat and called his allies to support his claim violently. The major clashes which took place in Podgorica left a deep mark on Montenegro's politics. DPS eventually split and called for an early election in 1998 as a solution for the existing crisis (Mochtak 2015).

Under the expectations of violent clashes and fear of massive demonstrations between proBulatović and pro-Đukanović supporters, the election was awaited with much concern (Mochtak 2015; Morrison 2018). Although less violent, several incidents were reported by members of the Socialist People's Party of Montenegro (SNP), the Liberal Alliance of Montenegro (LSCG), and Serbian People’s Party (SNS). Candidates and supporters complained about illegal house searches, intimidation of opposition voters by the police, and harassment during rallies. Incidents of intimidation and attacks were reported in Budva, Nikšić, and capital of Podgorica. During the DPS rally, a firecracker coupled with a rumor of a bomb caused panic and chaos with a number of injuries (OSCE 1998, 13). The overall 
situation in the country reflected the general crisis in Yugoslavia and declining popularity of Milošević and his allies. Montenegro was changing and although much can be said about the actual quality of the change that came in the following years, the second half of the 1990s was indeed about power struggle that was fuelled by newly emerged cleavages (Mochtak 2015). Since then, electoral violence is a regular part of Montenegrin elections. This can be documented on macro level by the change of size of ethnic groups and rising self-awareness of the Serbian minority. While in 1991 only $9.3 \%$ of population claimed to be Serbs, in 2003 it was already 32\% (with almost no change in size of the population).

Third path (UPES* BEP) covers only two cases of Albanian parliamentary elections in 1996 and 2005. It is a classic example of the existence of unfavourable institutional settings (UPES) not reflecting the magnitude of tensions interfering with the electoral arena. Contextual information on generally improving economic situation shows that electoral violence can occur even if the country is not in immediate economic crisis. Unproportional results as a consequence of unproportional electoral system often contextually refer to authoritarian tendencies that incumbent elites preferred over more proportional and fairer results. Especially Albania in the 1990s was constantly affected by extreme political strife between the Democratic Party of Albania (DPA) and the Socialist Party of Albania (SPA) and their effort to monopolize the public space. Due to an erosion of electoral support, the regime of President Sali Berisha (DPA) used intimidation and harassment as a campaigning tool that further increased the existing tension in the society. When the SPA won the election in 1997, the roles switched (Kaltsounis 2010; De Waal 2005). Public institutions were highly politicized and often acted as associated interest groups linked to political parties and their leaders. Electoral management body was not an exception with a huge dependency on the acting administration. In 2005, when the election was organized under a new electoral system with a supposedly more proportional outcome, the effort to monopolize the electoral outcome was again obvious. Although authorities claimed the goal to provide proportionality 'to the closest possible extent', the final design of the mixed electoral system with 100 out of 140 seats elected by majoritarian rules proved them wrong. In combination with the effort to 'balance' the Central Election Commission based on political representation, the existing conflicts 
easily destabilized the election administration and its effort to administrate the election effectivily (OSCE 2005).

The last path, present in all four models ( LEMB*LQD* BEP), refers to a context when electoral management bodies are quite competent and the economic performance is positive, but the overall standards of electoral integrity and good governance are profoundly violated. It covers the cases where the transformation from authoritarian rule to consolidated democracies was (and somewhere still is) affected by the effort to maximize electoral gains by alternative means. It explains electoral violence in most of the post-conflict parliamentary elections organized in Bosnia and Herzegovina as well as politically tensed elections in Macedonia. Especially the elections in Bosnia and Herzegovina are interesting here. Majority of the cases covered by the path are also present in other paths where ethnic diversity sets the contextual background for the electoral violence. It shows how ethnic division does not have to play a role in escalation of electoral violence as an alternative path might explain the very same phenomenon as well. It shows how the general narrative of ethnicity can oversimplify relations in divided communities where other structural preconditions do play a role. Violations of electoral integrity coming from poor or missing democratic qualities in combination with authoritarian tendencies create space for suspicions and distrust which may further affect the perception of opponents and their actions. The Post-Dayton settlement and its reflection in the electoral arena of Bosnia and Herzegovina can be definitely characterized through the strengthening of a peaceful electoral logic based on external pressure and oversight combined with routinizing non-violent practices for political coexistence. However, the process was not smooth and a number of issues affecting the freeness and fairness of elections did play a significant role during the elections (e.g. voters register or vote buying) (see overview OSCE 2018).

The five alternative paths splitting the results into four models can be discussed together as they cover only three cases (2001 parliamentary election in Montenegro, 2009 parliamentary election in Albania, and 1998 parliamentary election in Macedonia) and have similar theoretical value. The paths tell a story of an extreme form of political competition that escalates into violence through various shortcomings coming from a mixture of institutional and structural preconditions. As all the paths are 
complex, it is clear that close competition cannot produce electoral violence on its own. An example demonstrating this mechanism can be found in the 2009 parliamentary election in Albania where political polarization affected the course of campaigns driven by strong language and personal attacks. Intimidation and harassment of voters in order to force them to vote according to a certain pattern was quite common (e.g. university students or public servants). Although the Central Election Commission prepared and administered the elections professionally, its work was often affected by division along the political majority-minority lines. Problems were mainly noted during the appointment of lowerlevel election commissions (OSCE 2009, 7-8). General standards of electoral integrity were strongly affected by the initiative of the government to distribute secure ID card to every citizen without a valid passport, the only other means of voter identification. The short timeframe and the involvement of 354 LGU administrations, as well as the very limited time available to train administrative personnel, resulted in management and capacity deficits. Opposition parties subsequently questioned the administration of the process and alleged politically motivated manipulation that in combination with relatively close results raised suspicions about the validity of the results (OSCE 2009, 10).

These examples provide additional insight into the logic of electoral violence in the region while highlighting the conjunctural nature of the conditions under study. In other words, the conditions do not necessarily exert their impact on the outcome in isolation from one another, but have to be combined in order to reveal quasi-causal patterns. The paths show on a macro-level how electoral violence, in terms of potential drivers, differs across the Western Balkans and which cases are associated with the identified paths. Although the paths might seem theoretically close, they are not the same. The results need to be read as a roadmap of electoral violence in the region still affected by various political as well as social conflicts that co-exist and as such may affect the electoral competition.

\section{Conclusion}

Electoral violence is a phenomenon that occurs all around the world with varying dynamics that affect political stability and democratic performance. It is theoretically correct to argue that different contexts 
are defined by different factors which may be seen as drivers of contentious behaviour in an electoral arena often escalating into open hostility, even violence. The paper has approached this plurality as an inspiring perspective which sheds light on the logic of electoral violence in the Western Balkans. We tested seven conditions against the outcome of electoral violence in fsQCA analysis and identified four empirically robust paths that can explain electoral violence in the region while recognizing different contexts as well as cases covered by them.

The results of the paper generally confirm the general line of argumentation about the occurrence of electoral violence as discussed in the relevant literature. The electoral violence in the Western Balkans does occur during the transformation period as well in ethnically divided societies (Höglund 2009; Norris, Frank, and Martínez i Coma 2015). The paper also confirms the empirical relevance of conditions which are broadly discussed in studies focused on Africa or Southeast Asia (Fjelde and Höglund 2015; Opitz, Fjelde, and Höglund 2013). The advancement here is the identification of specific paths which map the phenomenon in the region of Western Balkans and establish links between particular cases and the potential drivers that explain them. The paper's contribution to the ongoing debate is threefold. First, the results show that the Western Balkans is a region where electoral violence has historically played an important role. Despite the progress the region has gone through in the past two decades, some of the countries still witness electoral violence regularly. Although not massive as electoral violence in Africa, it does hinder progress in the Western Balkans and affects the prospects for further development of some of the countries there. Moreover, the covered period shows how electoral violence has evolved in the past 25 years. We can see a slow but steady shift away from incidents based on brutal physical force to more subtle instances of psychological coercion indicating potential evolution of electoral violence as an effective strategy.

Second, paper shows how institutional conditions may interact with macro-structural settings and affect the occurrence of electoral violence. This potentially outlies a fruitful discussion on contextspecific drivers of electoral violence and their relevance in different contexts. It directly resonates with the debate on traveling concepts which might be especially relevant when discussing early warning signals and predictions of electoral violence for the purpose of policy relevant recommendations. 
Third, the conjunctural logic that defines each and every of the discussed paths shows that the scenarios of electoral violence in the region are always complex and potentially relevant conditions are never sufficient for the outcome on their own. Conjunctural causation is an analytical asset which allows us to see which conditions interacts together and create a path that is theoretically as well empirically relevant. The whole logic focuses on actual mechanisms which are at work when electoral violence occurs. Moreover, these logical paths are assigned to concrete cases which allows us to further discuss the identified mechanisms more thoroughly. This approach significantly differs from most of the published studies in the field as it follows a more analytically-driven strategy interested in complexity of electoral violence. The results should not be read as statistically significant rather empirically relevant findings that goes beyond the statistical testing.

Although the paper does not make a claim that these results are simply transposable to other cases, the approach and mechanisms suggested by this study might offer a useful way to start thinking about the roots of electoral violence in other regions as well. As elections do play an important role in our lives and the results always produce winners and losers, the importance of the conflict logic of elections needs to be fully recognized and understood in all its plurality.

\section{Notes}

1. The region of the Western Balkans is understood as a political construct that covers the states of the Balkan Peninsula that share certain socio-political features and face similar challenges and problems. The group includes Croatia, Serbia, Bosnia and Herzegovina, Montenegro, the Former Yugoslav Republic of Macedonia, Albania, and Kosovo.

2. The soft form entails no physical coercion but instead involves psychological methods applied to achieve a particular outcome; hard form refers to coercive pressure involving the use of physical force to influence the election, either in its outcome or its organization.

3. Organization refers to the element of collectiveness. It distinguishes whether acts of violence have been committed by individuals or by a group of people. 
4. Salience refers to the potential damage that may have been caused by the violence. At the low extreme, damage occurs only intermittently or secondarily. At the high extreme, almost every transaction inflicts damage, as the infliction and reception of damage dominate the interaction.

\section{References}

Arriola, L.R., and Johnson, C. 2012. APSA 2011 Annual Meeting Paper Election Violence in Democratizing States. pscourses.ucsd.edu/poli120n/ArriolaJohnson2012.pdf.

Bara, C. 2014. "Incentives and Opportunities: A Complexity-Oriented Explanation of Violent Ethnic Conflict.” Journal of Peace Research 51(6): 696-710. http://jpr.sagepub.com/cgi/doi/10.1177/0022343314534458.

Baumgartner, M., and Thiem, A. 2017a. "Model Ambiguities in Configurational Comparative Research.” Sociological Methods \& Research 46(4): 954-87.

— 2017b. "Often Trusted but Never (Properly) Tested: Evaluating Qualitative Comparative Analysis.” Sociological Methods \& Research online: 1-33.

Birch, S. 2011. Electoral Malpractice. Oxford, New York: Oxford University Press.

Birch, S., and Muchlinski, D. 2018. "Electoral Violence Prevention: What Works?” Democratization 25(3): 385-403.

Boone, C., and Kriger, N. 2012. "Land Patronage and Elections: Winners and Losers in Zimbabwe and Côte d'Ivoire.” In Voting in Fear: Electoral Violence in Sub-Saharan Africa, ed. Dorina Bekoe. Washington D.C.: United States Institute of Peace, 75-117.

Chandra, K. 2012. Constructivist Theories of Ethnic Politics. ed. Kanchan Chandra. New York: Oxford University Press.

Collier, P. 2009. Wars, Guns, and Votes : Democracy in Dangerous Places. New York: Harper.

Darmanović, S. 1992. "Montenegro: Destiny of a Satellite State." East European Reporter 5(2): $27-$ 29.

Dunning, T. 2011. "Fighting and Voting: Violent Conflict and Electoral Politics.” Journal of Conflict Resolution 55(3): 327-39.

Fjelde, H., and Höglund, K. 2015. "Electoral Institutions and Electoral Violence in Sub-Saharan Africa." British Journal of Political Science FirstView(Supplement-1): 1-24.

Gordon, C.E. 2013. Stagnation and Drift in the Western Balkans: The Challenges of Political, Economic and Social Change. Bern: Peter Lang.

Gutiérrez-Romero, R. 2014. “An Inquiry into the Use of Illegal Electoral Practices and Effects of Political Violence and Vote-Buying” eds. Laia Balcells and Patricia Justino. Journal of Conflict Resolution 58(8): 1500-1527. http://journals.sagepub.com/doi/10.1177/0022002714547902 (January 4, 2018).

Haesebrouck, T., and Thiem, A. 2017. "Burden Sharing in CSDP Military Operations.” Defence and Peace Economics: 1-18. https://www.tandfonline.com/doi/full/10.1080/10242694.2017.1320183 (September 13, 2018).

Hafner-Burton, E.M., Hyde, S.D., and Jablonski, R.S. 2013. "When Do Governments Resort to Election Violence?” British Journal of Political Science 44(01): 149-79.

Hayden, R.M. 2013. From Yugoslavia to the Western Balkans: Studies of a European Disunion, 19912011. Leiden: Brill.

Höglund, K. 2009. "Electoral Violence in Conflict-Ridden Societies: Concepts, Causes, and Consequences.” Terrorism and Political Violence 21(3): 412-27. 
Horowitz, D.L. 1985. Ethnic Groups in Conflict. Berkeley: University of California Press.

Huntington, S.P. 1991. “Democracy’s Third Wave.” Journal of Democracy 2(2): 12-34.

Kaltsounis, T. 2010. The Democratization of Albania. New York: Palgrave Macmillan.

Karl, T.L. 1990. "Dilemmas of Democratization in Latin America." Comparative Politics 23(1): 121.

Keil, S. 2014. State-Building in the Western Balkans: European Approaches to Democratization. Abingdon, New York: Routledge.

Koinova, M. 2013. Ethnonationalist Conflict in Postcommunist States : Varieties of Governance in Bulgaria, Macedonia, and Kosovo. Philadelphia: University of Pennsylvania Press.

Kuhn, P.M. 2015. “Do Contentious Elections Trigger Violence?” In Contentious Elections: From Ballots to Barricades, eds. Pippa Norris, Richard W Frank, and Ferran Martínez i Coma. New York: Routledge.

Levitsky, S., and Way, L. 2002. “The Rise of Competitive Authoritarianism.” Journal of Democracy 13(2): 51-65.

Lijphart, A. 1977. Democracy in Plural Societies : A Comparative Exploration. New Haven: Yale University Press.

Linz, J.J. 1990. “Transitions to Democracy.” The Washington Quarterly 13(3): 143-64.

Linz, J.J., and Stepan, A.C. 1996. Problems of Democratic Transition and Consolidation: Southern Europe, South America, and Post-Communist Europe. Baltimore: Johns Hopkins University Press.

Londregan, J.B., and Poole, K.T. 2011. "Poverty, the Coup Trap, and the Seizure of Executive Power.” World Politics 42(02): 151-83.

Mackie, J.L. 1965. “Causes and Conditions.” American Philosophical Quarterly 2(4): 245-64.

Mansfield, E.D., and Snyder, J.L. 2005. Electing to Fight: Why Emerging Democracies Go to War. Cambridge MA: MIT Press.

Mochtak, M. 2015. "Democratization and Electoral Violence in Post-Communism. A Study of Montenegro.” Southeast European and Black Sea Studies 15(1): 97-117.

_. 2016. "Fighting and Voting: Mapping Electoral Violence in the Region of Post-Communist Europe.” Terrorism and Political Violence.

Morrison, K. 2018. Nationalism, Identity and Statehood in Post-Yugoslav Montenegro. https://www.worldcat.org/title/nationalism-identity-and-statehood-in-post-yugoslavmontenegro/oclc/1006535602\&referer=brief_results (January 29, 2018).

Neofotistos, V.P. 2012. The Risk of War: Everyday Sociality in the Republic of Macedonia. Philadelphia: University of Pennsylvania Press.

Norris, P. 2014. Why Electoral Integrity Matters. New York: Cambridge University Press.

Norris, P., Frank, R.W., and Martínez i Coma, F. 2015. Contentious Elections: From Ballots to Barricades. New York: Routledge.

Opitz, C., Fjelde, H., and Höglund, K. 2013. "Including Peace: The Influence of Electoral Management Bodies on Electoral Violence.” Journal of Eastern African Studies 7(4): 713-31. https://www.tandfonline.com/doi/full/10.1080/17531055.2013.841024 (January 5, 2018).

OSCE. 1998. "Montenegro, Parliamentary Elections, 31 May 1998: Final Report.” http://www.osce.org/odihr/elections/montenegro/15101?download=true (January 29, 2018).

— . 2005. “Albania, Parliamentary Elections, 3 July 2005: Final Report.” http://www.osce.org/odihr/elections/albania/16856?download=true (January 29, 2018).

_ 2008. "Macedonia, Early Parliamentary Election, 1 June 2008, Final Report." http://www.osce.org/odihr/elections/fyrom/33153?download=true (January 29, 2018).

—. 2009. "Albania, Parliamentary Elections, 28 June 2009: Final Report.” http://www.osce.org/odihr/elections/albania/38598?download=true (January 29, 2018).

_. 2018. "Elections in Bosnia and Herzegovina." http://www.osce.org/odihr/elections/bih (January 29, 2018).

Pevehouse, J.C., Straus, S., and Taylor, C. 2012. Working paper, Department of Political Science, University of Wisconsin - Madison Perils of Pluralism: Electoral Violence and Competitive Authoritarianism in Sub-Saharan Africa.

Ragin, C.C. 2000. Fuzzy-Set Social Science. Chicago: University of Chicago Press.

—. 2006. "Set Relations in Social Research: Evaluating Their Consistency and Coverage." 
Political Analysis 14(3): 291-310.

- 2008. Redesigning Social Inquiry: Fuzzy Sets and Beyond. Chicago: University of Chicago Press.

Rapoport, D., and Weinberg, L. 2001. The Democratic Experience and Political Violence. eds. David Rapoport and Leonard Weinberg. London: F. Cass.

Reilly, B. 2001. Democracy in Divided Societies: Electoral Engineering for Conflict Management. Cambridge, New York: Cambridge University Press.

Rihoux, B., and Ragin, C.C. 2009. Configurational Comparative Methods: Qualitative Comparative Analysis (QCA) and Related Techniques. Thousand Oaks: SAGE.

Schedler, A. 2002. "The Nested Game of Democratization by Elections.” International Political Science Review 23(1): 103-22.

Schneider, C., and Wagemann, C. 2012. Set-Theoretic Methods for the Social Sciences: A Guide to Qualitative Comparative Analysis. Cambridge: Cambridge University Press.

Sisk, T.D. 1998. “Conclusions and Recommendations.” In Elections and Conflict Management in Africa, eds. Timothy D Sisk and Andrew Reynolds. Washington: United States Institute of Peace Press, 145-71.

— 2012. "Evaluating Election-Related Violence: Nigeria and Sudan in Comparative Perspective.” In Voting in Fear: Electoral Violence in Sub-Saharan Africa, ed. Dorina Bekoe. Washington D.C.: United States Institute of Peace, 39-74.

Thiem, A. 2016a. "Conducting Configurational Comparative Research With Qualitative Comparative Analysis: A Hands-On Tutorial for Applied Evaluation Scholars and Practitioners.” American Journal of Evaluation online: 1-14.

_ 2016b. "Standards of Good Practice and the Methodology of Necessary Conditions in Qualitative Comparative Analysis.” Political Analysis 24(4): 478-84.

_. 2018. "QCApro: Advanced Functionality for Performing and Evaluating QualitativeComparative Analysis [R Package QCApro Version 1.1-2].” https://cran.rproject.org/web/packages/QCApro/index.html (July 19, 2018).

Tilly, C. 2003. The Politics of Collective Violence. Cambridge: Cambridge University Press.

De Waal, C. 2005. Albania Today: A Portrait of Post-Communist Turbulence. London: I.B. Tauris.

Wilkinson, S. 2004. Votes and Violence Electoral Competition and Ethnic Riots in India. Cambridge; New York: Cambridge University Press.

Wimmer, A. 2013. Ethnic Boundary Making: Institutions, Power, Networks. New York: Oxford University Press. 
Table 1. Coding and calibration of electoral violence

\begin{tabular}{|c|c|c|c|}
\hline Hierarchy & Form/Organization/Salience & $\begin{array}{l}\text { Set-membership score } \\
\text { (electoral violence [EV]) }\end{array}$ & Cases \\
\hline$A_{2} B_{2} C_{2}$ & hard/collective/high & 1 & in the target set \\
\hline $\mathbf{A}_{1} \mathbf{B}_{2} \mathbf{C}_{2}$ & soft/collective/high & 0.9 & almost fully in the target set \\
\hline$A_{2} B_{2} C_{1}$ & hard/collective/low & 0.8 & mostly but not fully in the target set \\
\hline$A_{1} B_{2} C_{1}$ & soft/collective/low & 0.7 & more in than out of the target set \\
\hline $\mathrm{A}_{2} \mathrm{~B}_{1} \mathrm{C}_{2}$ & Hard/individual/high & 0.4 & $\begin{array}{l}\text { threshold area of more out than in } \\
\text { the target set }\end{array}$ \\
\hline$A_{2} B_{1} C_{1}$ & Hard/individual/low & 0.3 & more out of than in the target set \\
\hline $\mathrm{A}_{1} \mathrm{~B}_{1} \mathrm{C}_{2}$ & Soft/individual/high & 0.2 & $\begin{array}{l}\text { mostly but not fully out of the target } \\
\text { set }\end{array}$ \\
\hline$A_{1} B_{1} C_{1}$ & Soft/individual/low & 0.1 & almost fully out the target set \\
\hline $\mathrm{A}_{0} \mathrm{~B}_{0} \mathrm{C}_{\mathbf{0}}$ & Non-occurrence of violence & 0.0 & out of the target set \\
\hline
\end{tabular}

Table 2. Truth table

\begin{tabular}{|c|c|c|c|c|c|c|c|c|c|c|}
\hline LEMB & UPES & CC & LQD & ED & BEP & VRL & OUT & $\mathbf{n}$ & incl & cases \\
\hline 1 & 0 & 1 & 1 & 1 & 1 & 0 & 1 & 1 & 0.98 & MNE_PaE_2001 \\
\hline 1 & 0 & 1 & 1 & 0 & 0 & 1 & 1 & 1 & 0.97 & ALB_PaE_2009 \\
\hline 0 & 0 & 1 & 0 & 1 & 0 & 1 & 1 & 1 & 0.97 & MAC_PaE_1998 \\
\hline 1 & 0 & 0 & 1 & 1 & 0 & 1 & 1 & 1 & 0.93 & SRB_PaE_1997 \\
\hline 1 & 1 & 0 & 1 & 0 & 0 & 1 & 1 & 2 & 0.91 & ALB_PaE_1996; AL̄B_PaE_2005 \\
\hline 0 & 0 & 0 & 1 & 1 & 0 & 1 & 1 & 7 & 0.90 & $\begin{array}{c}\text { BaH_PaE_1996; BaH_PaE_1998; } \\
\text { BaH_PaE_2000; BaH_PaE_2002; } \\
\text { MAC_PaE_2008; MAC_PaE_2011; } \\
\text { MAC_PaE_2014 }\end{array}$ \\
\hline 0 & 0 & 0 & 1 & 1 & 1 & 1 & 1 & 2 & 0.85 & BaH_PaE_2014; AL̄B_PaE_2013 \\
\hline 1 & 0 & 0 & 1 & 1 & 1 & 1 & 1 & 3 & 0.84 & $\begin{array}{c}\text { SRB_PaE_1992; SRB_PaE_1993; } \\
\text { BaH_PaE_1990 }\end{array}$ \\
\hline 0 & 0 & 0 & 0 & 1 & 1 & 1 & 1 & 1 & 0.84 & MAC_PaE_2002 \\
\hline 0 & 0 & 0 & 0 & 1 & 0 & 1 & 1 & 1 & 0.83 & MAC_PaE_2006 \\
\hline 1 & 1 & 0 & 1 & 1 & 1 & 1 & 1 & 1 & 0.82 & SRB_PaE_1990 \\
\hline 0 & 0 & 0 & 1 & 0 & 0 & 1 & 1 & 3 & 0.79 & $\begin{array}{c}\text { CRO_PaE_1995; SRB_PaE_2000; } \\
\text { KSV_PaE_2010 }\end{array}$ \\
\hline 1 & 0 & 0 & 1 & 1 & 0 & 0 & 1 & 2 & 0.78 & MNE_PaE_1998; MNE_PaE_2006 \\
\hline 0 & 1 & 0 & 1 & 1 & 1 & 1 & 1 & 1 & 0.77 & CRO_PaE_1990 \\
\hline 0 & 0 & 0 & 1 & 1 & 0 & 0 & 1 & 1 & 0.77 & BaH_PaE_2006 \\
\hline 1 & 0 & 0 & 1 & 0 & 0 & 1 & 0 & 2 & 0.71 & KSV_PaE_2007; ALB_PaE_2001 \\
\hline 1 & 1 & 0 & 1 & 0 & 1 & 1 & 0 & 1 & 0.70 & AL̄B_PaE_1997 \\
\hline 0 & 0 & 0 & 1 & 1 & 1 & 0 & 0 & 1 & 0.62 & BaH_PaE_2010 \\
\hline 1 & 0 & 0 & 1 & 0 & 0 & 0 & 0 & 1 & 0.60 & KSV_PaE_2001 \\
\hline 0 & 1 & 0 & 1 & 1 & 1 & 0 & 0 & 2 & 0.59 & MAC_PaE_1990; MAC_PaE_1994 \\
\hline 1 & 0 & 0 & 1 & 0 & 1 & 1 & 0 & 2 & 0.56 & ALB_PaE_1991; ALB_PaE_1992 \\
\hline 1 & 0 & 0 & 1 & 0 & 1 & 0 & 0 & 1 & 0.49 & KSV_PaE_2004 \\
\hline 1 & 0 & 0 & 1 & 1 & 1 & 0 & 0 & 3 & 0.48 & $\begin{array}{c}\text { MNE_PaE_2002; MNE_PaE_2009; } \\
\text { MNE_PaE_2012 }\end{array}$ \\
\hline 0 & 0 & 1 & 0 & 0 & 1 & 1 & 0 & 2 & 0.48 & CRO_PaE_2015; SRB_PaE_2012 \\
\hline 0 & 0 & 0 & 1 & 0 & 1 & 1 & 0 & 2 & 0.48 & SRB_PaE_2014; KSV_PaE_2014 \\
\hline 0 & 0 & 0 & 0 & 0 & 1 & 1 & 0 & 1 & 0.39 & CRO_PaE_2011 \\
\hline 0 & 0 & 0 & 0 & 0 & 0 & 1 & 0 & 6 & 0.37 & $\begin{array}{l}\text { CRO_PaE_2000; CRO_PaE_2003; } \\
\text { CRO_PaE_2007; SRB_PaE_2003; } \\
\text { SRB_PaE_2007; SRB_PaE_2008 }\end{array}$ \\
\hline 0 & 1 & 0 & 1 & 0 & 1 & 1 & 0 & 1 & 0.35 & CRO_PaE_1992 \\
\hline
\end{tabular}


Table 3. Overview a model space produced by minimization procedure

\begin{tabular}{|c|c|}
\hline Models & Solution terms \\
\hline M1 & $E D^{*} V R L+E D^{*} \sim B E P+U P E S^{*} \sim B E P+\sim L E M B^{*} L Q D^{*} \sim B E P+($ LEMB*CC $) \rightarrow E V$ \\
\hline M2 & $E D^{*} V R L+E D^{*} \sim B E P+U P E S^{*} \sim B E P+\sim L E M B^{*} L Q D^{*} \sim B E P+(\mathrm{CC} * \mathrm{LQD}) \rightarrow \mathrm{EV}$ \\
\hline M3 & $E D^{*} V R L+E D^{*} \sim B E P+U P E S^{*} \sim B E P+\sim L E M B^{*} L Q D^{*} \sim B E P+\left(C^{*} \sim \mathrm{BEP}+\mathrm{CC} * \mathrm{ED}\right) \rightarrow \mathrm{EV}$ \\
\hline M4 & $\mathrm{ED}^{*} \mathrm{VRL}+\mathrm{ED}^{*} \sim \mathrm{BEP}+\mathrm{UPES}^{*} \sim \mathrm{BEP}+\sim \mathrm{LEMB}^{*} \mathrm{LQD}^{*} \sim \mathrm{BEP}+\left(\mathrm{CC}^{*} \sim \mathrm{BEP}+\mathrm{CC} * \sim \mathrm{VRL}\right) \rightarrow \mathrm{EV}$ \\
\hline
\end{tabular}

\begin{tabular}{|c|c|c|c|c|c|c|c|c|}
\hline Prime impl. & incl. & cov.r & cov.u & M1 & M2 & M3 & M4 & covered cases \\
\hline ED*VRL & 0.87 & 0.53 & 0.19 & 0.20 & 0.19 & 0.19 & 0.19 & $\begin{array}{l}\text { MAC_1998; SRB_1997; BaH_1996; BaH_1998; } \\
\text { BaH_2000; BaH_2002; MAC_2008; MAC_2011; } \\
\text { MAC_2014; BaH_2014; ALB_2013; SRB_1992; } \\
\text { SRB_1993; BaH_1990; MAC_2002; MAC_2006; } \\
\text { SRB_1990; CRO_1990 }\end{array}$ \\
\hline $\mathrm{ED} * \sim \mathrm{BEP}$ & 0.80 & 0.39 & 0.04 & 0.04 & 0.04 & 0.04 & 0.04 & $\begin{array}{l}\text { MAC_1998; SRB_1997; BaH_1996; BaH_1998; } \\
\text { BaH_2000; BaH_2002; MAC_2008; MAC_2011; } \\
\text { MAC_2014; MAC_2006; MNE_1998; MNE_2006; } \\
\text { BaH_2006 }\end{array}$ \\
\hline $\mathrm{UPES}^{*} \sim \mathrm{BEP}$ & 0.90 & 0.10 & 0.05 & 0.05 & 0.05 & 0.05 & 0.05 & ALB_1996; ALB_2005 \\
\hline$\sim \mathrm{LEMB} * \mathrm{LQD} *$ BEP & 0.83 & 0.35 & 0.06 & 0.06 & 0.06 & 0.06 & 0.06 & $\begin{array}{l}\text { BaH_1996; BaH_1998; BaH_2000; BaH_2002; } \\
\text { BaH_2006; MAC_2008; MAC_2011; MAC_2014; } \\
\text { CRO_1995; SRB_2000; KSV_2010 }\end{array}$ \\
\hline $\mathrm{CC}^{*} \sim \mathrm{BEP}$ & 0.79 & 0.05 & 0.00 & & & 0.02 & 0.02 & ALB_2009; MAC_1998 \\
\hline $\mathrm{CC}^{*} \sim \mathrm{VRL}$ & 0.84 & 0.06 & 0.00 & & & & 0.02 & MNE_2001 \\
\hline $\mathrm{CC} * \mathrm{ED}$ & 0.86 & 0.06 & 0.00 & & & 0.02 & & MNE_2001; MAC_1998 \\
\hline $\mathrm{CC}^{*} \mathrm{LQD}$ & 0.89 & 0.07 & 0.00 & & 0.03 & & & MNE_2001; ALB_2009 \\
\hline CC*LEMB & 0.98 & 0.05 & 0.00 & 0.03 & & & & MNE_2001; ALB_2009 \\
\hline $\begin{array}{l}\text { M1: Consistency }(0.82 \\
\text { M2: Consistency }(0.82 \\
\text { M3: Consistency }(0.81 \\
\text { M4: Consistency }(0.81\end{array}$ & $\begin{array}{l}\text {; Cove } \\
\text {; Cove } \\
\text {; Cove } \\
\text {; Cove }\end{array}$ & $\begin{array}{l}\text { age }(0.7 \\
\text { age }(0.7 \\
\text { age }(0.7 \\
\text { age }(0.7\end{array}$ & & & & & & \\
\hline
\end{tabular}

Note: n OUT = 1/0/C: 28/25/0; Number of multiple-covered cases: 12 ; 
Figure 1. Visualization of alternative paths

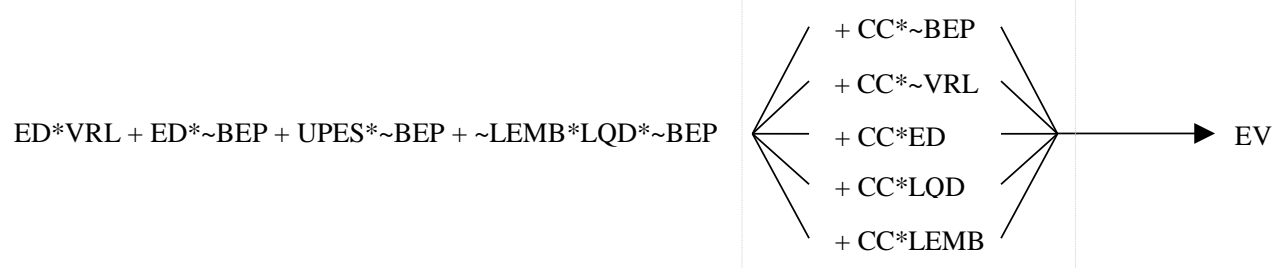

Empirical alternatives

Figure 2. Summary of paths and cases covered

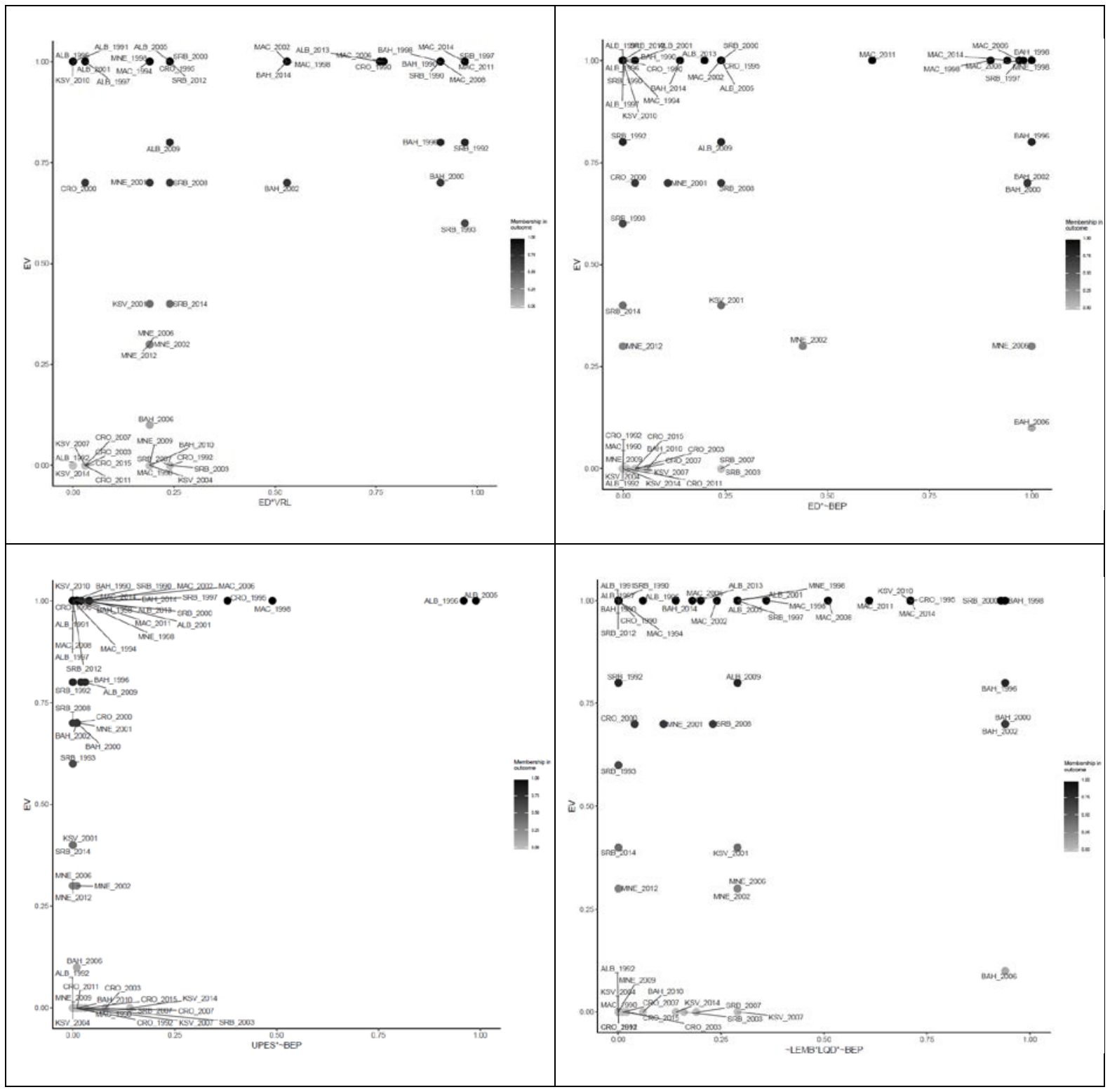




\begin{tabular}{|c|c|c|}
\hline condition & code & escription \\
\hline $\begin{array}{l}\text { Low quality of } \\
\text { democracy }\end{array}$ & LQD & $\begin{array}{l}\text { ow quality of democracy reflects the general democratic standards in the studied region focusing on the shortcomings rooted in the transformation period as well as existing } \\
\text { strictions imposed by (semi-)authoritarian governments. In this context, countries in transition, consolidating democracies, as well as authoritarian regimes may generate } \\
\text { centives for violence during elections as a result of frustration, strategic thinking or as a form of resistance (Norris, Frank, and Martínez i Coma 2015; Robertson 2013; Schedler } \\
\text { D13, 2006). }\end{array}$ \\
\hline Ethnic diversity & ED & $\begin{array}{l}\text { Ethnic division, traditionally driven by conflict behaviour based on emotions, ritualism, and "tribal" loyalties, may ignite strife between the categories "us" and "them" that } \\
\text { exacerbate violent action toward the members of allochthonous groups. Violence is then a physical manifestation of hostility which occurs periodically with a predefined pattern. } \\
\text { Election as an arena for political conflict is one of the places where the confrontation may take place and violence escalates (Baldwin, Faulkner, and Hecht 2006; Kroeber and } \\
\text { Kluckhohn 1952; Stevenson 2001). }\end{array}$ \\
\hline $\begin{array}{l}\text { Bad economic } \\
\text { performance }\end{array}$ & BEP & $\begin{array}{l}\text { Bad economic performance covers the dynamics of social conflicts based on various forms of material deprivation and poverty. Electoral violence is then seen as an extreme } \\
\text { manifestation of discontent against a poor economic situation or as an act of desperation (Moghaddam 2010; Olzak 1992). To cover the dynamic part of the electoral year, the } \\
\text { paper measures economic performance as GDP growth in the year when the election takes place and assumes that economic stagnation or decline can lead to the social } \\
\text { activation of economic deprivation (United Nations 2016). }\end{array}$ \\
\hline $\begin{array}{l}\text { Violation of } \\
\text { principles of rule of } \\
\text { law }\end{array}$ & VRL & $\begin{array}{l}\text { General standards of rule of law reflect the citizens' overall access to fair treatment, legal equality, and basic freedoms. It refers to an independent and capable judicial system } \\
\text { that is not corrupted, abused, or manipulated and all citizens and segments of society having equal access to it (Przeworski and Maravall 2003). In this context, violation of } \\
\text { principles of rule of law may ignite frustration as a part of existing grievances, especially when the principles are violated in favour of certain groups of segments of society } \\
\text { (Linz and Stepan 1996; O'Donnell 2010). }\end{array}$ \\
\hline $\begin{array}{l}\text { Unproportional } \\
\text { electoral system }\end{array}$ & UPES & $\begin{array}{l}\text { Proportionality of the electoral system takes into account one of the main desired qualities of electoral systems - proportionality of the electoral outcome (Bowler et al., 2005). } \\
\text { Although still inconclusive, an important part of the literature on electoral system design and post-conflict reconstruction advocates proportional electoral rules as part of a } \\
\text { broader package of power-sharing institutions as well as a tool reducing the chances for escalation of armed conflict in divided societies. In this context, disproportionality can } \\
\text { generate frustration about the results affecting the general acceptance of the electoral result (Fjelde and Höglund 2015; Lijphart 2004; McEvoy and O’Leary 2013; Reilly 2001; } \\
\text { Reilly and Reynolds 1999). }\end{array}$ \\
\hline $\begin{array}{l}\text { Low capacities of } \\
\text { electoral } \\
\text { management body }\end{array}$ & LEMB & $\begin{array}{l}\text { Electoral management bodies (EMBs) affect the incentives of major stakeholders in favour of non-violent strategies which stand in strict opposition to extra-legal activities as } \\
\text { viable alternatives. The dominant approach in the literature has been to emphasize the independence and non-partisanship of the EMBs as the most important factors for } \\
\text { guaranteeing the impartial imperative of electoral governance (Schedler 2002). If the electoral management body does not operate with enough capacities or independence to } \\
\text { conduct a free and fair election, the results may generate frustration and affect the will to accept them. Opitz at al. also found that more than the formal independence of electoral } \\
\text { management body, the level of inclusiveness creates structures of mutual restraint, where the ruling party is forced to engage in collaborative decision-making (Mozaffar 2002; } \\
\text { Opitz, Fjelde, and Höglund 2013). }\end{array}$ \\
\hline $\begin{array}{l}\text { Close electoral } \\
\text { competition }\end{array}$ & CC & $\begin{array}{l}\text { The closeness of results (or its expectation), may have a significant impact capable of modifying the dynamics of political competition in the electoral arena, especially when } \\
\text { combined with suspicion the election is not free and fair. In this context, electoral violence might be seen as an attractive option when opposing parties are more equally matched, } \\
\text { and electoral competition is perceived as the ultimate arena for solving an emerging conflict (Hafner-Burton, Hyde, and Jablonski 2013). This argument stands in contrast to the } \\
\text { assumption that the closer the margin of an election, the greater the incentive of the elected representative to pay attention to constituent preferences and demands - an approach } \\
\text { generally perceived as positive in democratic electoral competition (Dunning 2011; Levitt 1996; Stokes 1999). }\end{array}$ \\
\hline
\end{tabular}




\begin{tabular}{|c|c|c|c|c|c|}
\hline Condition & code & Logic & calibration & source & thresholds \\
\hline $\begin{array}{l}\text { Low quality of } \\
\text { democracy }\end{array}$ & LQD & $\begin{array}{l}\text { Low quality of democracy is measured with electoral democracy index coded by VDem project. The index anchor five components } \\
\text { [elected officials, free and fair elections, freedom of expression, associational autonomy, and inclusive citizenship] referring to } \\
\text { Dahl's (1971) extremely influential theoretical framework of polyarchy. The electoral democracy index is applied as a } \\
\text { measurement of actual qualities of electoral democracy of a regime on a scale of low to high (Coppedge, Gerring, and Lindberg } \\
\text { 2017; Diamond and Morlino 2005; Geissel, Kneuer, and Lauth 2016). The calibration is based on k-means clustering ( } \mathrm{k}=3 \text { ) and } \\
\text { further adjusted to reflect the contextual characteristics of the region. The full inclusion (low quality of democracy) is set at the } \\
\text { level 0.4; the threshold for the maximum ambiguity point is 0.6; and the threshold for full exclusion (high quality of democracy) } \\
\text { is } 0.8 \text {. }\end{array}$ & $\begin{array}{l}\text { direct } \\
\text { (logistic) }\end{array}$ & $\begin{array}{l}\text { Electoral } \\
\text { Democracy } \\
\text { Index } \\
\text { (Coppedge, } \\
\text { Gerring, and } \\
\text { Lindberg } \\
\text { 2017) }\end{array}$ & $\begin{array}{l}\text { (1) if } x \leq 0.4 \\
\text { (0.5) if } x=0.6 \\
\text { (0) if } x \geq 0.8\end{array}$ \\
\hline Ethnic diversity & ED & $\begin{array}{l}\text { Ethnic diversity is measured by the ethnic diversity score (EDS) calculated as a modified version of the Herfindahl-Hirschman } \\
\text { Index using ethnic divisions in the respective countries (the EDS is inverted so that higher scores indicate higher diversity [0-1], } \\
\text { where } 0 \text { means a fully homogenous state, and } 1 \text { a fully heterogonous state). Missing values are approximated or linearly modeled. } \\
\text { The calibration is based on empirical evidence collected in the Western Balkans where extreme scores of EDS do not occur (no } \\
\text { perfect homogeneity; no perfect heterogeneity), however, ethnocultural conflict may exist. } 0.0 \text { (fully out of the set) covers all the } \\
\text { cases where the Ethnic Diversity Score equals or is less than } 0.15 \text { ( } x \leq 0.15 \text { ) (society is homogenous; minorities do not exist or are } \\
\text { marginal in terms of political conflict); } 0.5 \text { (the point of ambiguity) is set at the level } x=0.35 \text {, where diversity may start to have a } \\
\text { relevant position in incentives for conflict; } 1.0 \text { (fully in the set) covers all the cases with the ethnic diversity score } x \geq 0.55 \text {, a } \\
\text { situation when ethno-cultural groups regularly challenge each other by size. }\end{array}$ & $\begin{array}{l}\text { direct } \\
\text { (logistic) }\end{array}$ & $\begin{array}{l}\text { Herfindahl- } \\
\text { Hirschman } \\
\text { Index }\end{array}$ & $\begin{array}{l}\text { (1) if } x \geq 0.55 \\
\text { (0.5) if } x=0.35 \\
\text { (0) if } x \leq 0.15\end{array}$ \\
\hline $\begin{array}{l}\text { Bad economic } \\
\text { performance }\end{array}$ & BEP & $\begin{array}{l}\text { Bad economic performance is measured by the growth of GDP per year (\%). Based on the perception of economic growth in the } \\
\text { region, the full inclusion (bad economic performance) is set at the level of } 0 \% \text { growth. The point of maximum ambiguity is the } \\
\text { level of } 2 \% \text { when it is not entirely clear whether the economy is doing well or is in crisis. The threshold for full exclusion } \\
\text { (economy is growing) is } 5 \% \text { when there are no doubts about the good performance of the economy in a given year. }\end{array}$ & $\begin{array}{l}\text { direct } \\
\text { (logistic) }\end{array}$ & $\begin{array}{l}\text { World Bank } \\
\text { (World Bank } \\
\text { 2016) }\end{array}$ & $\begin{array}{l}\text { (1) if } x \leq 0 \\
\text { (0.5) if } x=2 \\
\text { (0) if } x \geq 5\end{array}$ \\
\hline $\begin{array}{l}\text { Violation of } \\
\text { principles of rule } \\
\text { of law }\end{array}$ & VRL & $\begin{array}{l}\text { Violation of principles of rule of law is measured as a composite index of two components coded by VDem project: judicial } \\
\text { accountability (v2juaccnt) and judicial corruption decision (v2jucorrdc); (scale } 0-8 ; 8 \text {-best, } 0 \text {-worst). The threshold for full } \\
\text { inclusion (violation of principles of rule of law is present) is at the level of } 1 \text { referring to truly poor standards of judicial work and } \\
\text { independence. The point of most ambiguity is set at the level of } 5 \text { when the performance of judicial branch is far from perfect but } \\
\text { it can be seen as minimally functioning (the calibration utilizes threshold } 5.1 \text { in order to prevent the cases falling into this category). } \\
\text { The threshold for full exclusion (no violation of principles of rule of law) is } 8 \text { so it covers the fact that any lower index indicates } \\
\text { existing shortcomings and therefore qualitative difference we are interested in. }\end{array}$ & $\begin{array}{l}\text { direct } \\
\text { (logistic) }\end{array}$ & $\begin{array}{l}\text { VDem } \\
\text { (Coppedge, } \\
\text { Gerring, and } \\
\text { Lindberg } \\
\text { 2017) }\end{array}$ & $\begin{array}{l}\text { (1) if } x \leq 1 \\
\text { (0.5) if } x=5.1 \\
\text { (0) if } x \geq 8\end{array}$ \\
\hline $\begin{array}{l}\text { Unproportional } \\
\text { electoral system }\end{array}$ & UPES & $\begin{array}{l}\text { Unproportionality of electoral system on the outcome is measured with the Gallagher index. The full inclusion threshold } \\
\text { (unproportional outcome of the electoral system) is } 30 \text { when there is no doubt the system is unproportional on the outcome. The } \\
\text { full exclusion point (system is proportional on the outcome) is } 5 \text { as a reflection of Western Balkans' as well as international } \\
\text { standards assessing electoral systems and their performance. The threshold for the maximum ambiguity point is } 15 \text { when the } \\
\text { system can produce unproportional results but it does not have to stimulate frustration (although originally 15, the calibration } \\
\text { utilizes } 15.1 \text { in order to prevent the cases falling into this category). }\end{array}$ & $\begin{array}{l}\text { direct } \\
\text { (logistic) }\end{array}$ & $\begin{array}{l}\text { Election } \\
\text { Indices } \\
\text { (Gallagher } \\
\text { and Mitchell } \\
\text { 2005) }\end{array}$ & $\begin{array}{l}\text { (1) if } x \geq 30 \\
\text { (0.5) if } x=15.1 \\
\text { (0) if } x \leq 5\end{array}$ \\
\hline $\begin{array}{l}\text { Low capacities of } \\
\text { electoral } \\
\text { management } \\
\text { body }\end{array}$ & LEMB & $\begin{array}{l}\text { Low capacities of electoral management body are measured as a composite index of two components coded by VDem project: } \\
\text { EMB autonomy (v2elembaut) and EMB capacities (v2elembcap); (scale } 0-8 \text {; } 8 \text {-best, } 0 \text {-worst). The threshold for full inclusion (low } \\
\text { capacities) is at the level of } 2 \text { referring to truly poor standards of work combined with almost complete political dependency. The } \\
\text { full exclusion point (EMB is functioning correctly) is } 7 \text { reflecting the reality in the Western Balkans when even not a perfect score } \\
\text { might reflect highly capable EMB and its administration. The point of most ambiguity is set at the level of } 4.5 \text { as a plain } \\
\text { approximation of the interval midpoint. }\end{array}$ & $\begin{array}{l}\text { direct } \\
\text { (logistic) }\end{array}$ & $\begin{array}{l}\text { VDem } \\
\text { (Coppedge, } \\
\text { Gerring, and } \\
\text { Lindberg } \\
\text { 2017) }\end{array}$ & $\begin{array}{l}\text { (1) if } x \leq 2 \\
\text { (0.5) if } x=4.5 \\
\text { (0) if } x \geq 7\end{array}$ \\
\hline $\begin{array}{l}\text { Close electoral } \\
\text { competition }\end{array}$ & CC & $\begin{array}{l}\text { The closeness of the result is measured as the absolute difference between the percentage of votes acquired by the winner and the } \\
\text { runner-up. The full inclusion threshold (results are close) is } 1 \% \text { when it is clear the competition is very close. The full exclusion } \\
\text { point (results are not close) is } 5 \% \text { when it is clear the difference between the first and the second is big enough. The point of most } \\
\text { ambiguity is set at the level of } 3 \% \text { as a plain approximation of the interval midpoint (although originally } 3 \text {, the calibration utilizes } \\
3.1 \text { in order to prevent the cases falling into this category). }\end{array}$ & $\begin{array}{l}\text { direct } \\
\text { (logistic) }\end{array}$ & $\begin{array}{l}\text { Official } \\
\text { results } \\
\text { (various) }\end{array}$ & $\begin{array}{l}\text { (1) if } x \leq 1 \\
(0.5) \text { if } x=3.1 \\
(0) \text { if } x \geq 5\end{array}$ \\
\hline
\end{tabular}


Appendix C. Preliminary Truth Table

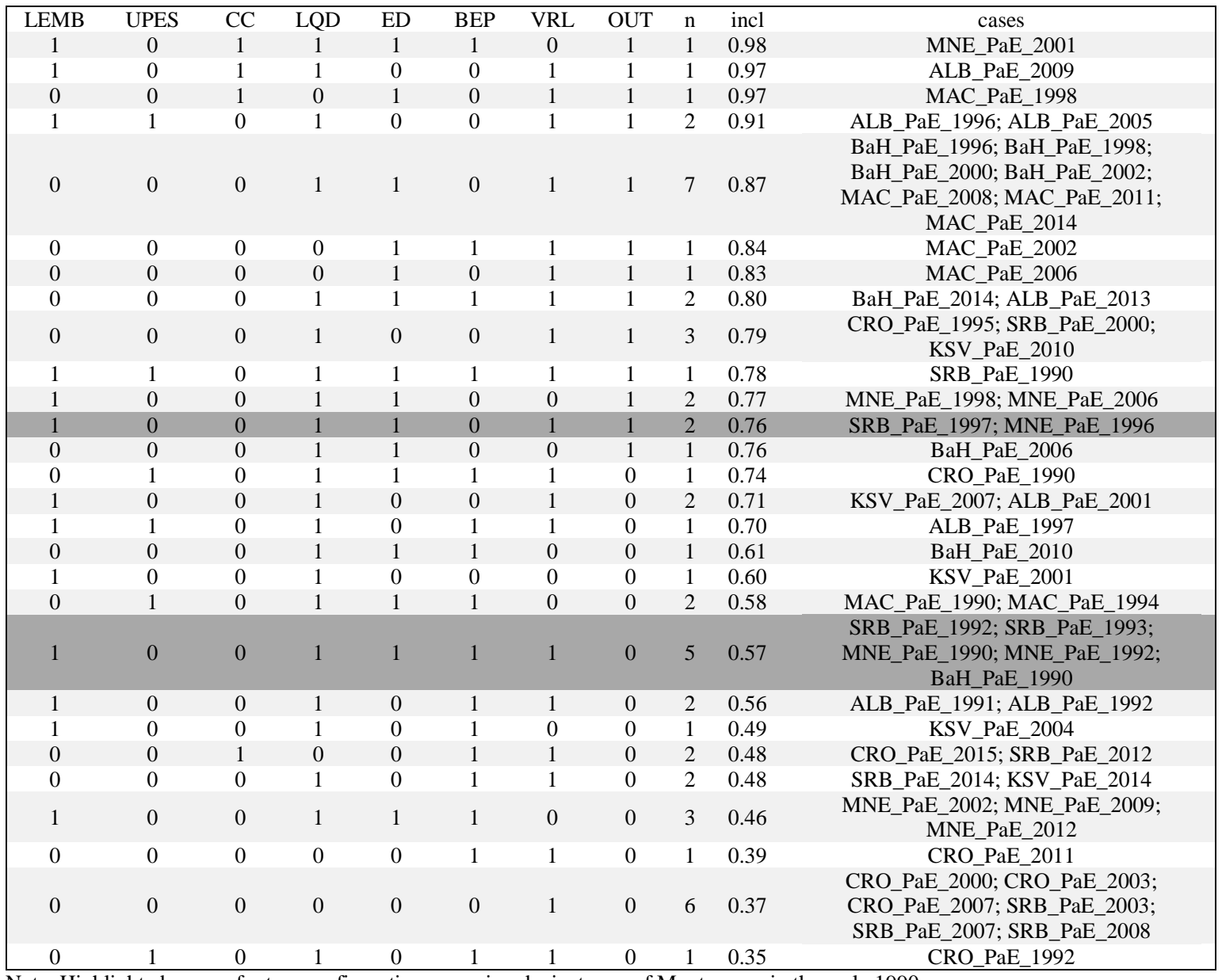

Note: Highlighted rows refer to a configurations covering deviant case of Montenegro in the early 1990s. 
Appendix D. Raw dataset

\begin{tabular}{|c|c|c|c|c|c|c|c|c|}
\hline CASE & LQD & ED & BEP & VRL & UPES & LEMB & CC & $\mathbf{E V}$ \\
\hline CRO_1990 & 0.15 & 0.4 & -11.6 & 4 & 22.3 & 5 & 18.2 & 1 \\
\hline CRO_1992 & 0.41 & 0.3 & -11.7 & 4 & 23.1 & 5 & 27 & 0 \\
\hline CRO_1995 & 0.42 & 0.3 & 6.8 & 4 & 14 & 5 & 26.9 & 1 \\
\hline CRO_2000 & 0.74 & 0.2 & 3.8 & 4 & 5.7 & 7 & 11.8 & 0.7 \\
\hline CRO_2003 & 0.78 & 0.2 & 5.6 & 4 & 9.6 & 7 & 11.3 & 0 \\
\hline CRO_2007 & 0.78 & 0.2 & 5.2 & 4 & 7.6 & 7 & 5.4 & 0 \\
\hline CRO_2011 & 0.84 & 0.2 & -0.3 & 5 & 12.3 & 7 & 17 & 0 \\
\hline CRO_2015 & 0.81 & 0.2 & 1.6 & 4 & 7.1 & 7 & 1.2 & 0 \\
\hline SRB_1990 & 0.25 & 0.5 & -11.6 & 3 & 24.6 & 2 & 30.3 & 1 \\
\hline SRB_1992 & 0.33 & 0.5 & -28.1 & 2 & 14 & 4 & 6.2 & 0.8 \\
\hline SRB_1993 & 0.33 & 0.5 & -30.4 & 2 & 9.2 & 4 & 20 & 0.6 \\
\hline SRB_1997 & 0.34 & 0.5 & 7.2 & 2 & 8 & 4 & 6.2 & 1 \\
\hline SRB_2000 & 0.49 & 0.3 & 7.8 & 4 & 5.3 & 6 & 50.3 & 1 \\
\hline SRB_2003 & 0.67 & 0.3 & 4.4 & 4 & 6.2 & 6 & 10 & 0 \\
\hline SRB_2007 & 0.66 & 0.3 & 5.9 & 5 & 4.9 & 6 & 5.9 & 0 \\
\hline SRB_2008 & 0.65 & 0.3 & 5.4 & 5 & 1.5 & 6 & 9 & 0.7 \\
\hline SRB_2012 & 0.61 & 0.3 & -1 & 5 & 6.5 & 6 & 2 & 1 \\
\hline SRB_2014 & 0.50 & 0.3 & -1.8 & 4 & 11 & 5 & 34.9 & 0.4 \\
\hline MNE_1998 & 0.32 & 0.7 & 4.6 & 6 & 4.1 & 4 & 13.3 & 1 \\
\hline MNE_2001 & 0.48 & 0.7 & 1.1 & 6 & 4.4 & 4 & 1.5 & 0.7 \\
\hline MNE_2002 & 0.50 & 0.7 & 1.9 & 6 & 4.2 & 4 & 9.6 & 0.3 \\
\hline MNE_2006 & 0.52 & 0.7 & 8.6 & 6 & 2.4 & 4 & 33.9 & 0.3 \\
\hline MNE_2009 & 0.52 & 0.7 & -5.7 & 6 & 6.6 & 4 & 35.1 & 0 \\
\hline MNE_2012 & 0.52 & 0.7 & -2.7 & 6 & 2.3 & 4 & 22.8 & 0.3 \\
\hline BAH_1990 & 0.25 & 0.7 & -11.6 & 3 & 1.5 & 4 & 5.1 & 1 \\
\hline BAH_1996 & 0.33 & 0.6 & 54.2 & 3 & 7 & 6 & 100 & 0.8 \\
\hline BAH_1998 & 0.35 & 0.6 & 16.6 & 3 & 6.7 & 6 & 100 & 1 \\
\hline BAH_2000 & 0.37 & 0.6 & 5.4 & 3 & 4.1 & 6 & 100 & 0.7 \\
\hline BAH_2002 & 0.37 & 0.6 & 5 & 5 & 4.3 & 6 & 100 & 0.7 \\
\hline BAH_2006 & 0.35 & 0.6 & 5.7 & 6 & 5.6 & 6 & 100 & 0.1 \\
\hline BAH_2010 & 0.35 & 0.6 & 0.8 & 6 & 4.6 & 6 & 100 & 0 \\
\hline BAH_2014 & 0.34 & 0.6 & 1.2 & 5 & 5 & 6 & 100 & 1 \\
\hline KSV_2001 & 0.30 & 0.3 & 25.7 & 6 & 1 & 4 & 20 & 0.4 \\
\hline KSV_2004 & 0.49 & 0.3 & -0.9 & 6 & 1.8 & 4 & 16.6 & 0 \\
\hline KSV_2007 & 0.47 & 0.2 & 8.3 & 5 & 4.4 & 4 & 11.7 & 0 \\
\hline KSV_2010 & 0.48 & 0.1 & 3.3 & 5 & 3.3 & 5 & 7.4 & 1 \\
\hline KSV_2014 & 0.55 & 0.1 & 1.2 & 2 & 14.1 & 5 & 5.1 & 0 \\
\hline MAC_1990 & 0.28 & 0.5 & -11.6 & 6 & 33.6 & 5 & 6.4 & 0 \\
\hline MAC_1994 & 0.47 & 0.5 & -1.8 & 6 & 33.6 & 5 & 15.2 & 1 \\
\hline MAC_1998 & 0.62 & 0.5 & 3.4 & 5 & 15 & 6 & 3 & 1 \\
\hline MAC_2002 & 0.64 & 0.5 & 1.5 & 5 & 8 & 6 & 16.4 & 1 \\
\hline MAC_2006 & 0.67 & 0.5 & 5.1 & 4 & 5.2 & 6 & 9.2 & 1 \\
\hline MAC_2008 & 0.60 & 0.5 & 5.5 & 3 & 3.4 & 6 & 25.1 & 1 \\
\hline MAC_2011 & 0.52 & 0.6 & 2.3 & 2 & 5.7 & 6 & 6.2 & 1 \\
\hline MAC_2014 & 0.47 & 0.6 & 3.8 & 2 & 4.5 & 5 & 18.3 & 1 \\
\hline ALB_1991 & 0.36 & 0 & -28 & 3 & 10.2 & 2 & 17.5 & 1 \\
\hline ALB_1992 & 0.46 & 0.1 & -7.2 & 3 & 9.2 & 3 & 33.6 & 0 \\
\hline ALB_1996 & 0.40 & 0.1 & 9.1 & 3 & 25.4 & 3 & 35.1 & 1 \\
\hline ALB_1997 & 0.39 & 0.2 & -10.8 & 3 & 26.9 & 3 & 7.5 & 1 \\
\hline ALB_2001 & 0.50 & 0.2 & 7.9 & 3 & 8.1 & 4 & 4.5 & 1 \\
\hline ALB_2005 & 0.56 & 0.3 & 5.8 & 3 & 30.2 & 4 & 4.7 & 1 \\
\hline ALB_2009 & 0.58 & 0.3 & 3.4 & 3 & 7.6 & 4 & 0.7 & 0.8 \\
\hline ALB_2013 & 0.54 & 0.4 & 1.4 & 3 & 5.6 & 5 & 10.8 & 1 \\
\hline
\end{tabular}




\section{Appendix References}

Baldwin, John R, Sandra L Faulkner, and Michael L Hecht. 2006. A Moving Target: The Illusive Definition of Culture. A Moving Target: The Illusive Definition of Culture. Redefining Culture: Perspectives across the Disciplines. Mahwah, N.J.: Lawrence Erlbaum Associates.

Coppedge, Michael, John Gerring, and Staffan I. Lindberg. 2017. "Varieties of Democracy.” 2017. https://www.vdem.net/en/.

Dahl, Robert A. 1971. Polyarchy: Participation and Opposition. New Haven: Yale University Press.

Diamond, Larry Jay, and Leonardo Morlino. 2005. Assessing the Quality of Democracy. Baltimore: Johns Hopkins University Press. https://www.worldcat.org/title/assessing-the-quality-ofdemocracy/oclc/60881691\&referer=brief_results.

Dunning, T. 2011. "Fighting and Voting: Violent Conflict and Electoral Politics.” Journal of Conflict Resolution 55 (3):32739. https://doi.org/10.1177/0022002711400861.

Fjelde, Hanne, and Kristine Höglund. 2015. "Electoral Institutions and Electoral Violence in Sub-Saharan Africa.” British Journal of Political Science FirstView (Supplement-1):1-24. https://doi.org/10.1017/S0007123414000179.

Gallagher, Michael, and Paul Mitchell. 2005. The Politics of Electoral Systems. Oxford: Oxford University Press.

Geissel, Brigitte, Marianne Kneuer, and Hans-Joachim Lauth. 2016. "Measuring the Quality of Democracy: Introduction.” International Political Science Review 37 (5). SAGE PublicationsSage UK: London, England:571-79. https://doi.org/10.1177/0192512116669141.

Hafner-Burton, Emilie M, Susan D Hyde, and Ryan S Jablonski. 2013. "When Do Governments Resort to Election Violence?” British Journal of Political Science 44 (01). Cambridge University Press:149-79. https://doi.org/10.1017/S0007123412000671.

Kroeber, A L, and Clyde Kluckhohn. 1952. Culture: A Critical Review of Concepts and Definitions. Cambridge, MA: The Museum.

Levitt, Steven D. 1996. "How Do Senators Vote? Disentangling the Role of Voter Preferences, Party Affiliation, and Senator Ideology.” The American Economic Review 86 (3):425-41.

Lijphart, Arend. 2004. "Constitutional Design for Divided Societies.” Journal of Democracy 15 (2). The Johns Hopkins University Press:96-109. https://doi.org/10.1353/jod.2004.0029.

Linz, Juan J, and Alfred C Stepan. 1996. Problems of Democratic Transition and Consolidation: Southern Europe, South America, and Post-Communist Europe. Baltimore: Johns Hopkins University Press.

McEvoy, Joanne, and Brendan O’Leary. 2013. Power Sharing in Deeply Divided Places. Philadelphia: University of Pennsylvania Press.

Moghaddam, Fathali M. 2010. The New Global Insecurity : How Terrorism, Environmental Collapse, Economic Inequalities, and Resource Shortages Are Changing Our World. Santa Barbara, CA: Praeger Security International.

Mozaffar, Shaheen. 2002. "Patterns of Electoral Governance in Africa’s Emerging Democracies.” International Political Science Review 23 (1). Sage PublicationsLondon:85-101. https://doi.org/10.1177/0192512102023001005.

Norris, Pippa, Richard W Frank, and Ferran Martínez i Coma. 2015. Contentious Elections: From Ballots to Barricades. New York: Routledge.

O’Donnell, Guillermo A. 2010. Democracy, Agency, and the State: Theory with Comparative Intent. Oxford, New York: Oxford University Press.

Olzak, Susan. 1992. The Dynamics of Ethnic Competition and Conflict. Stanford, CA: Stanford University Press.

Opitz, Christian, Hanne Fjelde, and Kristine Höglund. 2013. "Including Peace: The Influence of Electoral Management Bodies on Electoral Violence.” Journal of Eastern African Studies 7 (4):713-31. https://doi.org/10.1080/17531055.2013.841024.

Przeworski, Adam, and José María Maravall. 2003. Democracy and the Rule of Law. Cambridge: Cambridge University Press.

Reilly, Benjamin. 2001. Democracy in Divided Societies: Electoral Engineering for Conflict Management. Cambridge, New York: Cambridge University Press.

Reilly, Benjamin, and Andrew Reynolds. 1999. Electoral Systems and Conflict in Divided Societies. Washington, D.C.: National Academy Press.

Robertson, Graeme. 2013. “Protesting Putinism: The Election Protests of 2011-2012 in Broader Perspective.” Problems of Post-Communism 60 (2):11-23.

Schedler, Andreas. 2002. “The Menu of Manipulation.” Journal of Democracy 13 (2). The Johns Hopkins University Press:36-50. https://doi.org/10.1353/jod.2002.0031. . 2006. Electoral Authoritarianism: The Dynamics of Unfree Competition. Boulder, CO: L. Rienner Publishers. . 2013. The Politics of Uncertainty: Sustaining and Subverting Electoral Authoritarianism. New York: Oxford University Press.

Stevenson, Nick. 2001. Culture and Citizenship. London; Thousand Oaks, CA: SAGE.

Stokes, Susan. 1999. “What Do Policy Switches Tell Us About Democracy?” In Democracy, Accountability, and Representation, edited by Adam Przeworski, Susan Stokes, and Bernard Manin, 98-130. Cambridge: Cambridge University Press.

United Nations. 2016. "United Nations Statistics Division - National Accounts.” http://unstats.un.org/unsd/snaama/selbasicFast.asp.

World Bank. 2016. “Data. The World Bank.” http://data.worldbank.org/. 